\title{
RENDAHNYA KESADARAN BERDEMOKRASI MASYARAKAT PONOROGO DAN LEMAHNYA KEBIJAKAN PUBLIK (STUDI KASUS: TEMUAN “MONEY POLITIC" OLEH BAWASLU PONOROGO PADA PEMILU 2019)
}

\author{
Saka Prasada \\ Rafi Febryan Alfiasnyah \\ Dian Suluh Kusuma Dewi \\ Fakultas Ilmu Sosial dan Ilmu Politik Universitas Muhammadiyah Ponorogo \\ sakaprassada22@gmail.com \\ raffalalfiansyah@gmail.com, \\ suluh.dian@gmail.com
}

\begin{abstract}
Abstrak
Demokrasi merupakan suatu system yang fleksibel bagi masyarakat Indonesia, dimana system ini telah memberikan ruang kebebasan untuk bernarasi, berekspresi, berpartisipasi, maupun berkontribusi dalam membangun bangsa ini. Melalui banyak cara, masyarakat dapat secara langsung untuk menunjukan eksistensinya tanpa harus menerima unsur paksaan dari siapapun. Termasuk di dalam kontestasi pemilu, dimana seharusnya rakyat menunjukan integritasnya melalui kesadaran yang baik dalam berdemokrasi. Munculnya politik uang dewasa ini adalah bukti dari cidera akut yang melanda demokrasi Indonesia, termasuk di Ponorogo. Faktanya masih banyak masyarakat Ponorogo yang belum bisa memaknai demokrasi secara utuh, dan mudah tergoda dengan hasrat politik oleh para oknum. Hal ini terbukti melalui temuan dari Bawaslu Ponorogo pada Pemilu 2019 kemarin, berhasil melakukan OTT terhadap warga masyarakat di Kec. Jambon yang hendak melakukan pendistribusian uang panas. Maka dari itu penelitian ini bertujuan untuk mengukur bagaimana kualitas dan indeks masyarakat Ponorogo untuk ber-demokrasi selama ini dalam lingkar "Money Politic" dan masih lemahnya Kebijakan Politik dalam Pemilu. Dengan menggunakan studi dokumentasi, maka data-data valid dari pemberitaan mediamedia kredibel pun terkumpul menjadi satu padanan fakta yang tidak terbantahkan.
\end{abstract}

Kata Kunci : Kesadaran Masyarakat, Demokrasi, Kebijakan Politik, Pemilu

\section{PENDAHULUAN}

Indonesia merupakan negara dengan kapasitas penduduk yang besar, serta sarat dengan problematika di segala aspek. Di dalam suatu negara yang menganut system demokrasi seperti Indonesia, rasanya wajar saja jika permasalahan ataupun 
ketidakcocokan muncul mengingat banyaknya perbedaan maupun kepentingan yang tidak sama. Demokrasi sendiri merupakan satu padanan system yang mendefinisikan adanya suatu kesepakatan bersama antar banyak orang, serta diraih dengan cara melakukan jajak pendapat maupun diskusi yang tentunya melibatkan kontribusi dari banyak pemikiran.

Hal diatas sejalan dengan konsep dari Kantrapawira (2004) yakni, asas fundamental dalam demokrasi menyatakan bahwa rakyat adalah sebagai unsur yang melekat dan wajib untuk berpartisipasi secara penuh untuk memperjuangkan tujuan bersama dalam negara (Kenlies Era, 2019). Disini dapat dikatakan bahwa masyatakat juga memiliki ruang untuk melakukan upaya maupun kontribusi bagi tumbuh kembang negara, melaui cara-cara legal dan konstitusional tentunya. Artinya demokrasi memerlukan pembaharuan agar sistemnya terus berjalan.

Sudah sejak lama demokrasi menjadi system yang dianut oleh banyak negara, termasuk negara Indonesia sendiri. Kemudian dapat kita ketahui bersama, bahwa salah satu wujud nyata dari bejalannya demokrasi di Indonesia adalah dengan adanya kontestasi maupu ajang Pemilu yang telah berlangsung sejak lama. Pada dasarnya tujuan Pemilu di indonesia adalah untuk melaksanakan estafet kepemimpinan melalui suara rakyat secara langsung (voting).

Namun faktanya sering ditemukan kasus money politic yang ikut menciderai kualitas Pemilu termasuk di Ponorogo. Sebagai contoh pada Pemilihan Bupati di tahun 2015, banyak kisruh \& kontoversi yang terjadi akibat dari dugaan kuat terhadap praktik money politic yang dilakukan oleh salah 1 pasangan calon. Gugatan tersebut berasal dari kandidat Cabup Sugiri Sancoko yang melakukan protes terhadap keputusan dari KPUD Ponorogo (Anggoro \& Hilman, 2018).

Berdasarkan fakta dilapangan seluruh gugatan yang dilayangkan memang telah diliput oleh berbagai macam media baik cetak, elektronik, televisi, maupun online. Adapun selain permasalahan Pilkada, di Ponorogo juga memiliki beberapa catatan hitam terkait kasus money politic, seperti kasus OTT yang dilakukan oleh Bawaslu Ponorogo terhadap warga yang terlibat dalam Pemilu (Pileg) 2019 kemarin. Kasus OTT yang terjadi di Ponorogo pada Pemilu kemarin juga sangat ramai dalam pemberitaan media local dan nasional. 
Politik uang (money politic) nampaknya memang terus bercokol dan menjadi momok besar bagi republik ini, hampir kerap terjadi pada setiap rekrutmen politik, termasuk dalam Pilkada, Pileg, maupun Pilpres. Praktik money politik sebenarnya juga tergantung dari sisi masyarakat sendiri, artinya adalah bagaimana cara pandang serta sikap yang muncul. Banyak masyarakat yang masih memiliki tingkat kesadaran rendah, serta seolah menutup mata terhadap pelanggaran demokrasi ini.

Bahkan menurut temuan dari Kana (2001), money politik justru dianggap sebagai bentuk kedermawanan oleh para calon pemimpin atau elite politik. Selain itu menurut Sosio (2004) juga menemukan fakta, bahwa masyarakat malah merasa yakin apabila seorang calon pemimpin/legislator telah berbaik hati untuk memberikan uang ataupun barang kepada mereka (Kenlies Era, 2019).

Seluruh problematika di atas merupakan hal yang menarik dan tidak ada habisnya untuk dikaji secara ilmiah. Maka dari itu tulisan ini bermaksud untuk memberikan gambaran tentang kesadaran befikir dari sebagian besar masyarakat Ponorogo dalam lingkar (money politic). Dimana masih ditemukan banyak kasus yang terjadi, dan menandakan bahwa indeks kesadaran demokrasi masih rendah.

Sesuai dengan judul diatas,, penelitian ini bersifat deskriptif kualitatif yang tujuanya memberikan gambaran tentang topic penelitian yakni Rendahnya Kesadaran Ber-Demokrasi Masyarakat Ponorogo \& Lemahnya Kebijakan Politik (Studi Kasus : Temuan Money Politic oleh Bawaslu Ponorogo Pada Pemilu 2019).

Teknik pengumpulan data dalam penelitian ini menggunakan :

a. Studi Dokumentasi dan;

b. Observasi tidak terlibat (tidak langsung)

Karena data diperoleh dari berbagai kabar dan berita di masa lalu, dalam portal pemberitaan media online yang selanjutnya dapat dikaji dan ditafsirkan. Kemudian observasi tidak langsung merupakan cara yang dilakukan oleh peneliti tanpa menggugah kesadaran dari objek yang sedang diteliti (Masyarakat Ponorogo yang terlibat money politic). 
Teknik analisis data dalam penelitian ini menggunakan analisis model interaktif Hubberman \& Miles, yang meliputi 3 komponen pokok yaitu

1. reduksi data,

2. sajian data, dan;

3. penarikan kesimpulan

Semuanya dilakukan terhadap segala data yang diperoleh dan telah disimpulkan selama dan sesudah proses penelitian berlangsung.

\section{PEMBAHASAN}

\section{A. Catatan Money Politik di Ponorogo}

1. Dilansir dari (KOMPAS.com, 2019) pada Selasa, 16 April 2019 diberitakan bahwa pihak Bawaslu Ponorogo telah berhasil mengamankan sejumlah barang bukti berupa uang dengan total Rp. 66.130.000. Jumlah uang sebesar ini diduga kuat untuk melakukan praktik money politic yang bersumber dari para caleg.

Adapun temuan tersebut dilakukan di rumah seorang warga yang ada di Kec. Jambon Ponorogo (berdasarkan dari laporan warga sekitar). Setelah itu komisioner Bawaslu Ponorogo pun bergegas untuk menghubungi pihak terkait seperti aparat, maupun panwascam. Selain itu walau uang sejumlah 66 juta belum dibagikan, namun 15 orang yang bertugas untuk mendistribusikan tetap diamankan.

2. Dilansir dari (Tribunnews.com, 2019) pada Selasa 16 April 2019 juga memberitakan tentang penemuan sejumlah uang yang dilakukan oleh Bawaslu Ponorogo di kediaman salah seorang warga Kec.Jambon. Berita ini sekaligus mengkonfirmasi akan kebenaran pemberitaan yang beredar seperti halnya pemberitaan oleh (KOMPAS.com, 2019).

Hanya saja terdapat keterangan tambahan mengenai jenis uang yang ditemukan yakni berupa pecahan 20.000 \& 10.000 menurut keterangan dari Marji Nurcahyo selaku Divisi Penindakan Pelanggaran Pemilu. Selain itu ditemukan daftar calon penerima uang (sejumlah 1500 orang) dari 
salah satu caleg, yang enggan disebutkan nama \& partainya oleh Marji kepada (karna masih dalam proses klarifikasi).

3. (SURABAYA INSIDE.com, 2019)

Berita ini bahkan terdengar hingga media Surabaya, dimana tidak ada pemberitaan yang berbeda pada intinya. Namun ada keterangan tambahan dari pemberitaan media ini, seperti :

1. Ada informasi tentang penyebutan nama Desa "Sendang" secara terang-terangan yang ada di Kec. Jambon Ponorogo.

2. Terdapat nominal yang rinci apabila warga masyarakat mau mencoblos caleg secara paket (DPR-RI, DPRD Provinsi, DPRD Kabupaten/Kota) yakni senilai Rp. 70 ribu. Jika hanya bersedia menyoblos caleg DPRRI, maka diberikan 30 ribu rupiah.

3. Ditemukan alat peraga berupa surat suara untuk para pemilih.

\section{B. Lemahnya Kebijakan dalam Konteks Pemilu (Ancaman Pidana \& Denda)}

Walaupun sudah ada aturan tentang sanksi pidana bagi pelaku maupun penerima politik uang, namun nampaknya hal tersebut terkadang tidak dihiraukan oleh sebagain besar masyarakat. Namun ada perbedaan hukum yang mencolok antara Pemilu dan Pilkada, dimana hal ini menjadi kurang progresif dalam mengatur kasus pengadaan politik uang. Yakni :

a. Pada Pasal 187A ayat (1) (Undang-Undang No.10 Tahun 2016 Tentang Pemilihan Kepala Daerah (PILKADA), 2016) diatur bahwa sanksi atas money politic dapat berlaku bagi "penerima" maupun "pemberi”.

b. Sedangkan dalam Pasal 523 (Undang-Undang Nomor 7 Tahun 2017 tentang Pemilihan Umum, 2017) ancaman hukuman/pidana hanya berlaku bagi pemberi uang, peserta, dan tim kampanye. Sedangkan para pemilih/penerima tidak mendapatkan ancaman pidana sama sekali. Hal ini menjari rancu jika dibandingkan dengan UU Pilkada yang jauh lebih tegas dalam mengatur ancaman pidana. 


\section{Paradigma Pelik dalam Demokrasi}

Menurut (Juwaini, 2019) selaku Komisioner Bawaslu Ponorogo, dalam naskah publikasi yang dapat diakses di https://bawaslu.ponorogo.go.id/, menyatakan bahwa di masa kini politik uang berevolusi menjadi suatu makna simbolis yang oleh masyarakat dianggap sebagai wujud nyata dari seorang calon pemimpin/legislator.

Masyarakat menganggap bahwa antara dirinya dan para elite politik adalah sama-sama membutuhkan, terutama bagi masyarakat golongan menengah ke bawah yang berpenghasilan pas-pasan. Sehingga pada akhirnya mereka ingin segera beranjak dari kegelisahan (dengan cara melakukan sesuatu yang instant) ketika Pemilu ataupun Pilkada tiba.

Seharusnya para calon pemimpin/legislator adalah mereka yang benarbenar memiliki integritas dan meminta bantuan kepada rakyat untuk ikut berpartisipasi dalam mendukungnya, lalu membawa harapan yang jujur \& siap menerima segala kritik/masukan. Atau dengan kata lain rakyat pun dapat secara ramai-ramai dan sukarela untuk melakukan semacam kontrak politik (Juwaini, 2019).

Sebaliknya, politik uang merupakan kontradiksi dari semangat demokrasi. Dimana ukuran integritas tidak lagi dibutuhkan, karena segalanya hanya diukur berdasarkan gelimang harta yang digelontorkan. Pada akhirnya semua ini menciptakan peluang, untuk pecundang.

\section{KESIMPULAN}

Politik uang masih menjadi momok yang mengkhawatirkan bagi berjalannya demokrasi di Indonesia. Baik kontestasi Pemilu maupun Pilkada, keduanya sama-sama melahirkan praktik picik yang dilakukan oleh oknum elite. Masyarakat Ponorogo dapat dikatakan masih sangat rendah dalam menyikapi fenomena maupun intrik-intrik politik, sehingga dengan mudahnya dapat terhasut syahwat politik dari para calon. Hal ini sangat tidak baik jika terus bertahan lama, mengingat apa yang didapat dalam sehari belum tentu sebanding dengan penderitaan yang mungkin di dapat di kemudian hari. 


\section{DAFTAR PUSTAKA}

Anggoro, A. D., \& Hilman, Y. A. (2018). Kisruh Pilkada Kabupaten Ponorogo. Jurnal Riset Komunikasi, 1, 203-212.

Juwaini. (2019). Mempersoalkan Money Politic. https://bawaslu.ponorogo.go.id/2019/04/06/mempersoalkan-moneypolitik/

Kenlies Era, S. (2019). Revitalisasi Pendidikan Politik Melalui Pembentukan Kampung Anti Money Politic (Political Education Revitalization Through The Establishment Of Anti Money Politic Village). Jurnal Ilmu Pemerintahan Dan Sosial Politik, 7(2), 111-121.

KOMPAS.com. (2019). Bawaslu Ponorogo Amankan Rp 66 Juta Diduga untuk Politik Uang Pileg 2019. https://surabaya.kompas.com/read/2019/04/16/13362521/bawasluponorogo-amankan-rp-66-juta-diduga-untuk-politik-uang-pileg-2019

SURABAYAINSIDE.com. (2019). Lagi, OTT Money Politic di Ponorogo. https://surabayainside.com/lagi-ott-money-politic-di-ponorogo/

Tribunnews.com. (2019). Bawaslu Amankan 15 Warga Ponorogo, Temukan Uang Rp 66 Juta dan Daftar Penerima Money Politic Caleg. https://tribunnews.com/regional/2019/04/16/bawaslu-amankan-15-wargaponorogo-temukan-uang-rp-66-juta-dan-daftar-penerima-money-politiccaleg

Undang-Undang No.10 Tahun 2016 Tentang Pemilihan Kepala Daerah (PILKADA). (2016).

Undang-Undang Nomor 7 Tahun 2017 tentang Pemilihan Umum. (2017). 